\title{
A SHORT STORY ABOUT EAST-WEST INTERACTIONS
}

More than Lisbon, London or Paris, Amsterdam was the European centre of trade in Asian commodities in the 17th and 18th centuries. Spices, pewter and copper, tea and coffee, tropical woods and many more articles from the East were imported in huge quantities, generating part of the wealth and prosperity of the Dutch. For us art historians, the other items that came with the shipments such as Chinese and Japanese porcelain, Oriental lacquer, Indian chintzes, Chinese silks, jewellery and exotic curiosities are interesting because they deeply influenced the material culture in the Netherlands and Europe, finding their way into interior design, fashion and daily life. In turn, Western information, techniques and objects had an impact on Asian cultures and art. These mutual influences exemplify aspects of a much wider globalisation that took place during this period.

The pivotal function of Amsterdam, catering in Asian goods for the domestic as well as for the international markets in the West, could never have been achieved without the continuous supply by the Dutch East India Company (VOC), which was established in 1602. Being a shareholder's company, enough money was available to build an efficient trading network in Asia, reaching from Arabia to Japan. Ships were the lifeline, carrying the cargoes and relaying the communication, supported by meticulous administration and bookkeeping. Batavia, the Company's Asian headquarters and trading centre on the island of Java, was home to an amazing melting pot of Asians and Europeans, ruled by a de facto independent government of high-ranking VOC officials. Aiming at monopolistic trade, the 17 th century was a period of expansion for the VOC, while the 18th century was a period of consolidation that was marred by their struggle with English and French competition.

Before focusing on some examples of interaction in decorative art, I would like to remind you that we should never forget that this entire field of research exists only by the grace of the efforts and pains of those individuals involved through the years: sailors and traders, craftsmen, shop owners, collectors and many, many other men and women. They deserve our respect and gratitude.

This would almost be a book even if I treated only the most important aspects of Dutch-Asian interaction in some depth. Let us therefore focus on only a few characteristic and interesting examples of Chinese and Japanese porcelain, Dutch Delftware, Indian chintz, Japanese and Dutch lacquer and Chinese silk. It may also be fruitful to demonstrate a few different approaches to studying the objects. In order to keep this essay within the set boundaries, the equally fascinating stories of Western influences on Asian societies and of Western chinoiserie and Japonism have tow wait for another occasion $_{2023}$ 04:56:14AM 


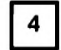

Figure 1

Large dish, kraak porcelain, diameter 51 cm, China, 1620-1640, Groninger Museum, inv. no. 1980-0169.

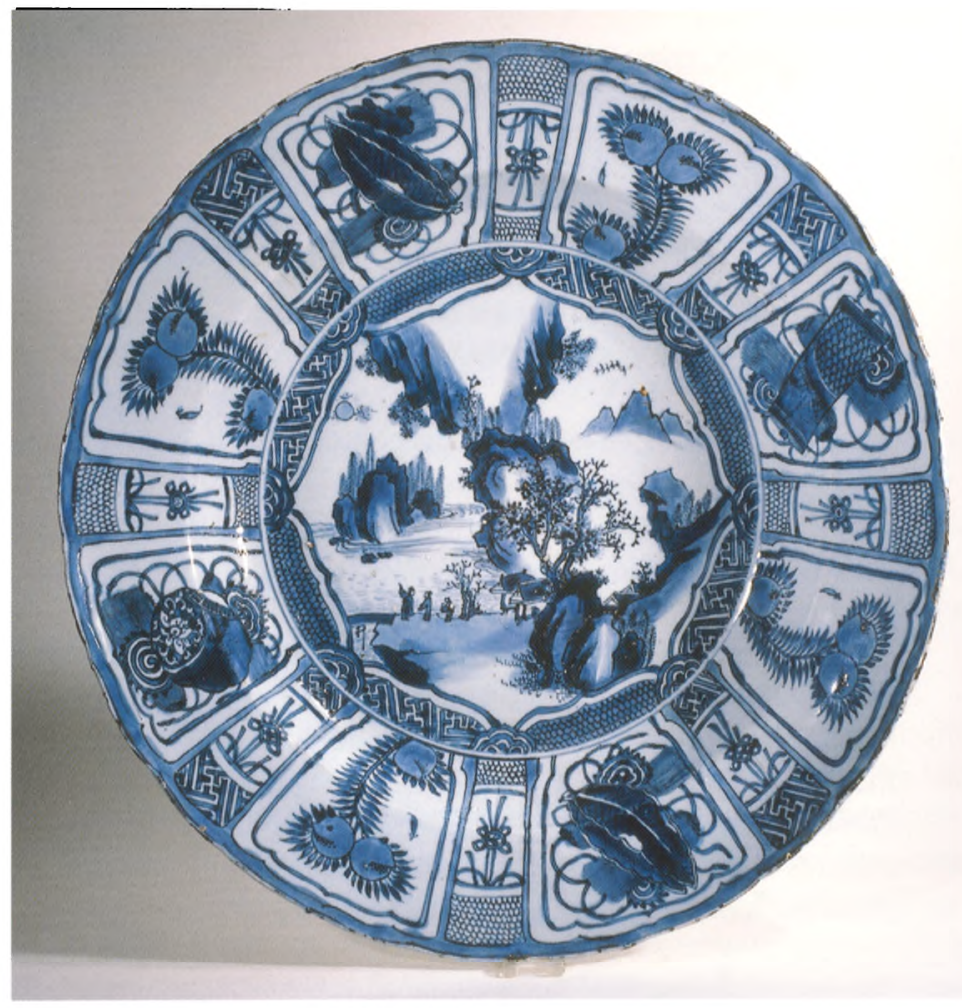

\section{Ceramics}

For the Dutch in the early 17 th century, kraak porcelain was their first encounter with China and with porcelain as a material. This porcelain was popular from the moment that it was sold in the Netherlands in 1602 and 1604 because it was thin and strong, the contrasting decorations in blue on white were highly exotic and its novelty made it status enhancing. Porcelain was displayed on the dinner table, figured prominently in still life paintings and soon became an indispensable item in the interiors of well-to-do Dutch. The VOC tried to import porcelain on a regular basis, but was dependent on an intermittent supply, because they could not buy kraak in China, as the Chinese refused them entry to the country. Trade in porcelain became more structured after the Company settled on Taiwan (1624) from where they started ordering porcelain from Mainland China in 1634. This resulted in cooperation with Chinese trade conglomerates, which could access kilns producing another type of porcelain. This so-called transitional porcelain was less uniformly made, of better quality and offered an entirely new range of decorations. These direct contacts also enable the VOC to order specific Western shapes such as candlesticks, salts and beer mugs (see figs. 1, 2 and 3).

The fall of the Ming dynasty in 1644 marked the beginning of a period of unrest and civil war in China. Production and transportation of porcelain was disrupted and small cargoes were only available occasionally. The VOC, which needed a steady supply for the Dutch market, found an alternative in

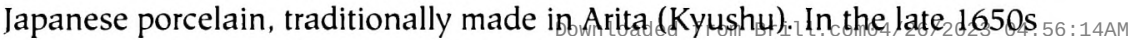
the Company, operating from their Factory on Deshima in Nagasaki'Bay,ee access 

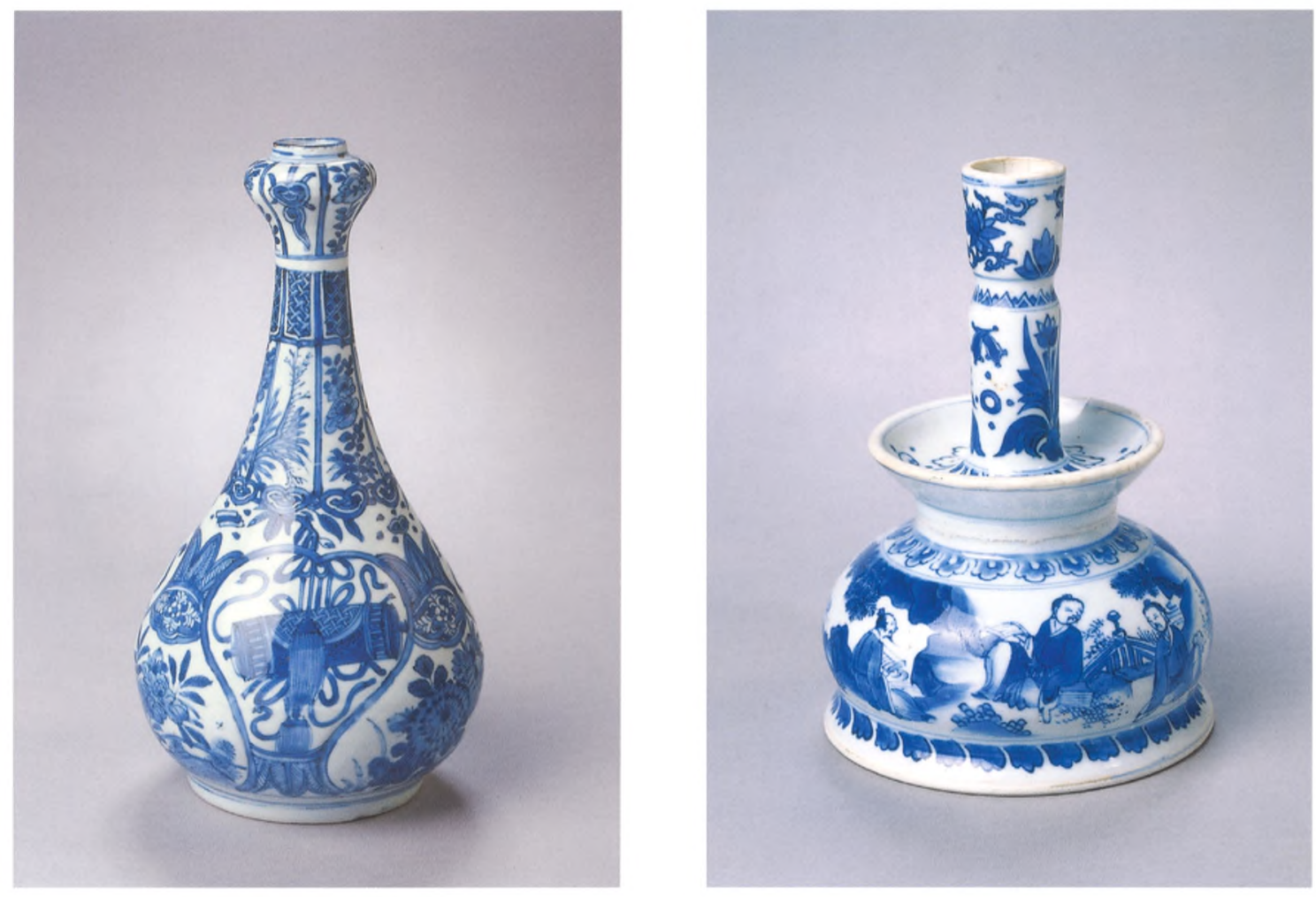

Figure 2

Bottle, kraak porcelain, height $29 \mathrm{~cm}$, China, 1600-1620, Groninger Museum, inv. no. 19840160.

Figure 3

Candlestick, transitional porcelain, height $22.5 \mathrm{~cm}$ China, 1635-1645, Groninger Museum, inv. no. 1989-0102. started trading in Japanese export porcelain. Having exclusive rights in Japan, the VOC held a monopoly on this porcelain trade. The Japanese assortments differed from those of the Chinese, if only because they included polychrome enamelled wares. In Arita, Western shapes were made to order, too. In Holland, these Japanese porcelains - blue or enamelled - were a resounding success, but the price was high and the supply could barely meet the demand. Underglaze-blue export wares initially imitated the well-known Chinese kraak or transitional pieces, but the enamelled wares, not dependent on models of Chinese coloured wares for the Dutch, showed Japanese-style decorations and shapes from the outset (figs. 4 and 5).

In the Netherlands, the shortage of Chinese porcelain and the scarcity of Japanese wares stimulated a large-scale production of earthenware imitations. Technical innovations resulted in a thin body, covered on both sides with a white tin glaze. The town of Delft became the centre of production of this socalled faience. As in Japan, imitations of Chinese styles initially dominated the decorations of blue Delftware, but there was much creativity when it came to shapes, opening up new domestic and international markets (fig. 6).

After Emperor Kangxi (1662-1722) re-established order in China in the early 1680 s, the porcelain kilns resumed production and tried to recapture the lost markets. New assortments in shape and decoration were offered at low prices and junks distributed the wares throughout Southeast Asia, including Batavia. In 1683 already, the VOC stopped ordering porcelain in Japan and reverted to Chinese wares that were shipped free to Bataviacby Chinese $04: 56: 14 \mathrm{Am}$ merchants. Besides the VOC, private dealers in Batavia also bought these access 


\section{$\ll$ Figure 4}

Dish, the border design imitating Chinese kraak porcelain, diameter 38.3 cm, Japan, 1660-1680,

\section{Groninger Museum,} inv. no. 1961-0217.

\section{< Figure 5}

Large dish, Imari, diameter $46.8 \mathrm{~cm}$, Japan, 1700-1720, Groninger Museum, inv. no. 1986-418.

\section{Figure 8 >}

Jar, Dutch Delftware, decorated with a chinoiserie in 'Delft Imari', marked PAK, Grieksche A factory, height $33.5 \mathrm{~cm}$, 1701-1722, Groninger Museum, inv. no. 19870452.

\section{< Figure 6}

Ewer, Dutch Delftware, shape and decoration inspired by Chinese transitional porcelain, marked AK, Grieksche A factory, height $16.8 \mathrm{~cm}$, 1686-1701, Groninger Museum, inv. no. 198779.

\section{$<$ Figure 7}

Wall sconce, imitating a European model, the decoration in Chinese style, $31.5 \times 20 \mathrm{~cm}$, China, ca. 1700, Groninger Museum, inv. no. 1995-0122.

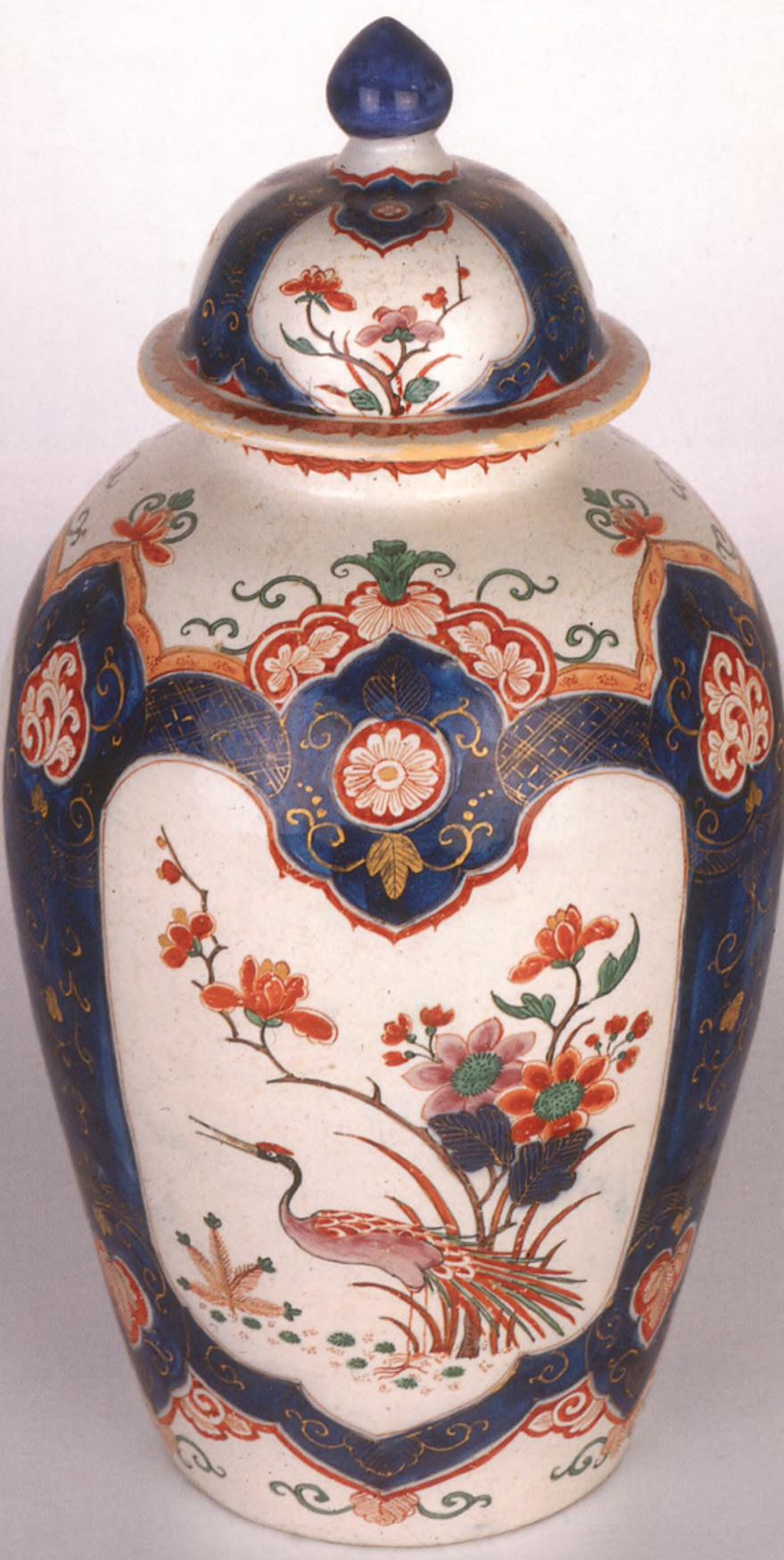


Figure 9

Daniel Marot, Design

for a Porcelain Cabinet, engraving from the series Nouveaux Livre da Partements, ca. 1700. From P. Jessen, Das Ornamentwerk des Daniel Marot, Berlin 1892, p. 153.

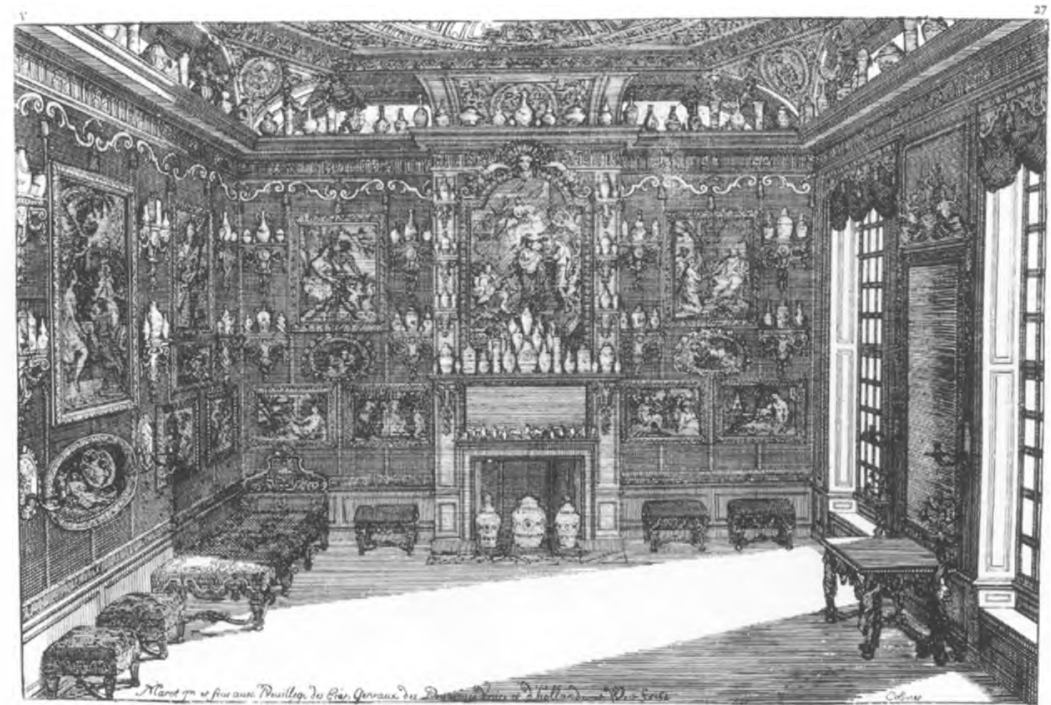

The abundance of Chinese porcelain that was available around 1700 , exclusively imported by private dealers, led to different uses in the Dutch interior. No longer valued as individual exotic objects worthy of being depicted or displayed as such, they became more appreciated as decorative items. The interior designer Daniel Marot (1661-1752) a Frenchman employed by William and Mary and their successors, published prints showing chimney pieces and walls covered with porcelain in geometrical compositions, placed on consoles or lining doors and windows. For him and his many adepts, it was the overwhelming effect of the accumulated shapes and colours that took precedence. Porcelain rooms and cabinets were installed all over Europe, but very few have survived (fig. 9).

The modern fashion of drinking tea and coffee, as well as changing habits in dining and laying the table, called for new shapes. Porcelain was still the ultimate material, but its popularity and the profits gleaned resulted in the invention of hard porcelain in Meissen, Germany, in around 1710. During the 18th century, this fashionable European porcelain catered to the top end of the market, while the cheaper Chinese porcelain was for the common markets. The VOC joined other Western companies when direct trade with Canton in China began in 1729. This was mainly to participate in the tea trade, but porcelain always was included in the return cargoes until the Company bankrupted in 1794 .

The VOC's porcelain trade in the 18th century dealt mostly with utility wares. The importation of more special pieces, such as chine de commande - porcelain ordered after Western models, often with designs sourced from Western prints - was left to private individuals (fig. 10).

The above illustrates the contextual methoc using historical and economic data, to position porcelain (or other objects) in a cultural context. An ultimate example is porcelain salvaged from a shipwrs ck such $_{\text {a }}$ as the cargo from the $6: 14 \mathrm{Am}$ Geldermalsen, a VOC East-Indiaman that wrecked in 1752 during its ${ }^{\text {ia }}$ free access 


\section{Figure 10}

Tureen, commande, depicting porcelain production in jingdezhen, height $24.5 \mathrm{~cm}$, China, 1740-1760, Groninger Museum, inv. no. 1988 187.

\section{Figure 11}

Butter tub, salvaged from the wreck of the Geldermalsen (1752), height $6 \mathrm{~cm}$, base $11.5 \mathrm{x}$ $9 \mathrm{~cm}$, China, Groninger Museum, inv. no. 1986 0894. Shaped after a wooden Dutch model; the enamelled decoration is decayed.
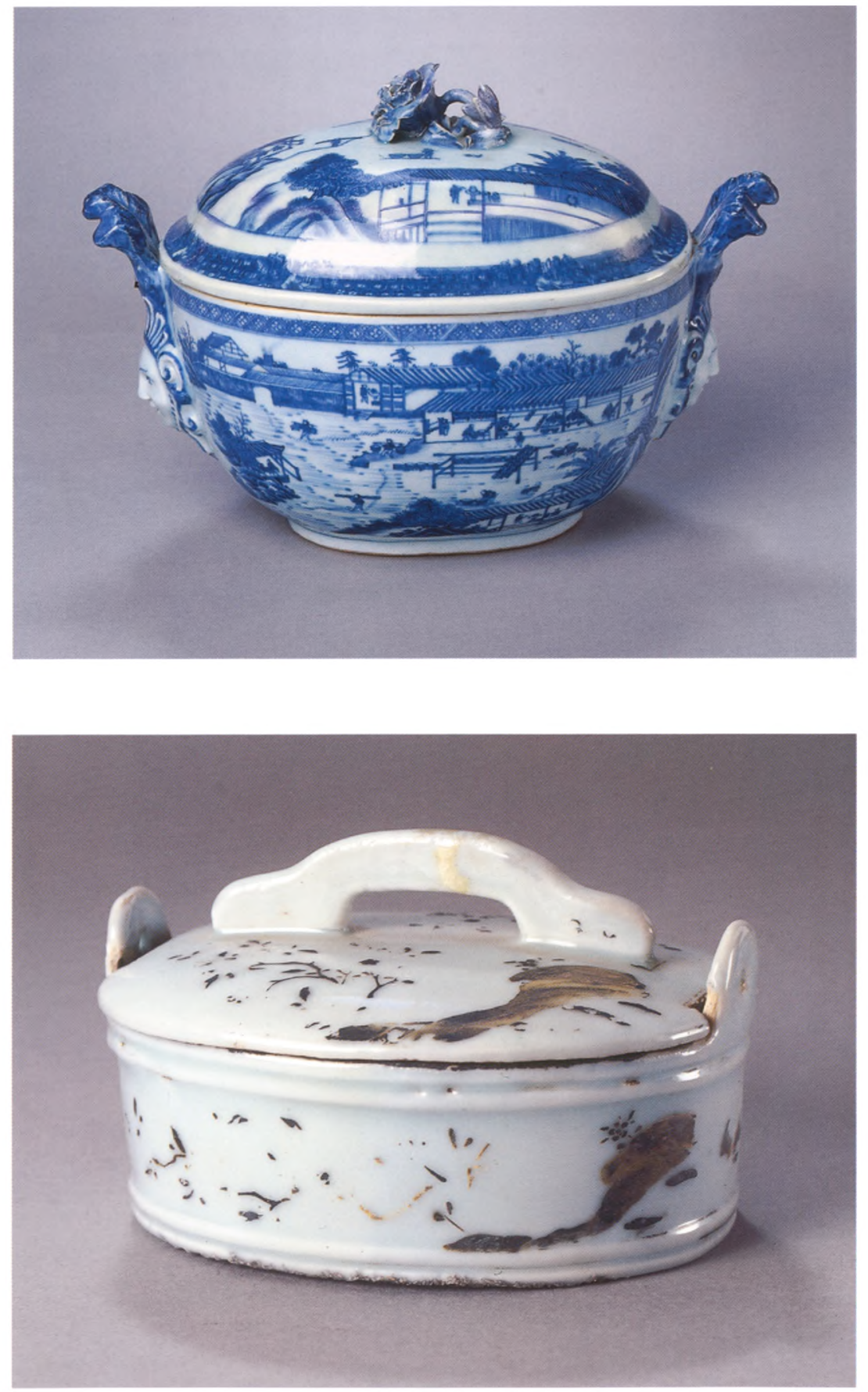

homebound voyage from China. The porcelain can be dated exactly, the assortment tells us about use, demand and quality, while the higher quality pieces not documented in the surviving shipping list provide insights into the private porcelain trade (fig. 11).

Porcelain has received considerable attention here, reflecting the time I spent on this subject with my students. By necessitye other items are discussed less: 14AM extensively. 


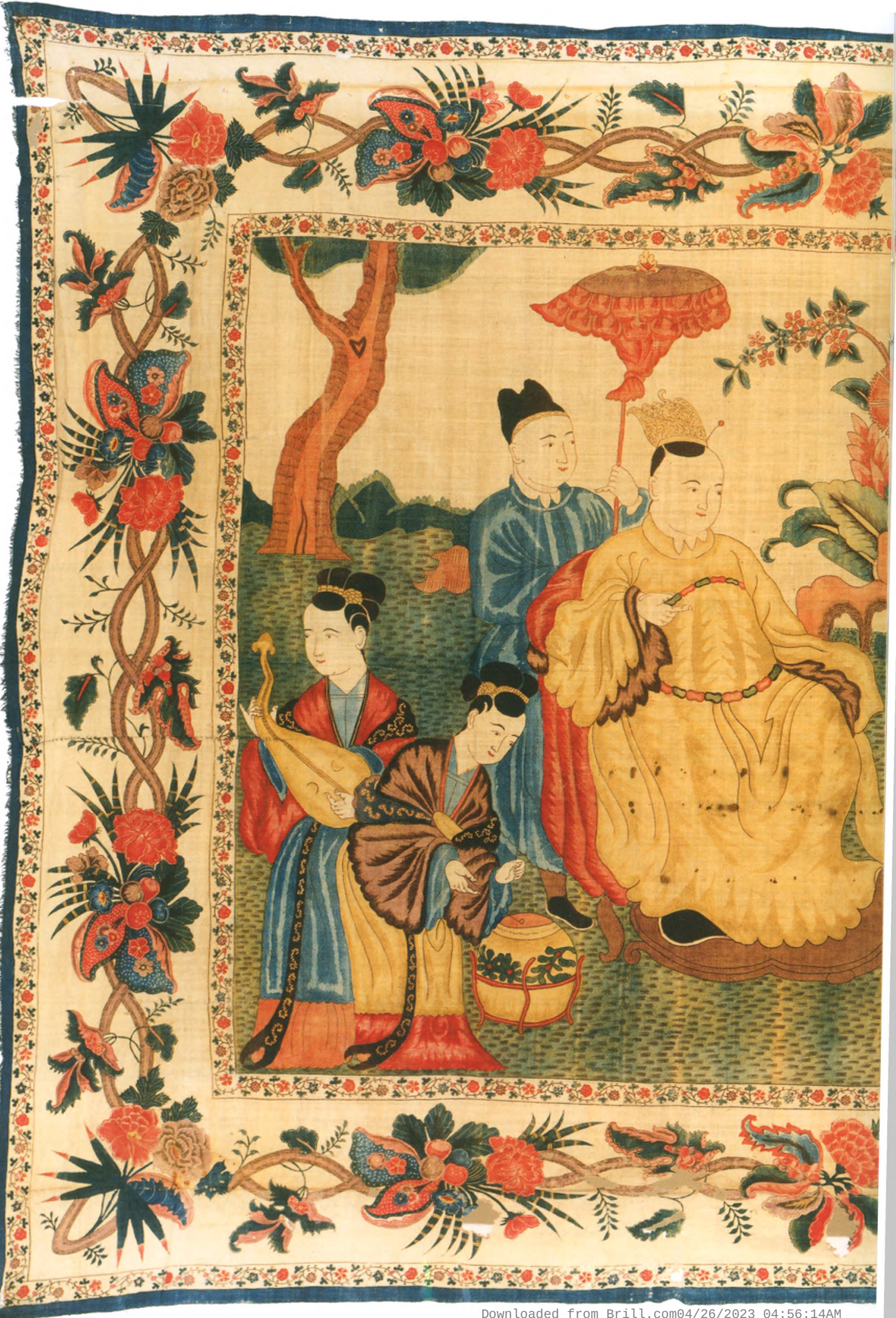




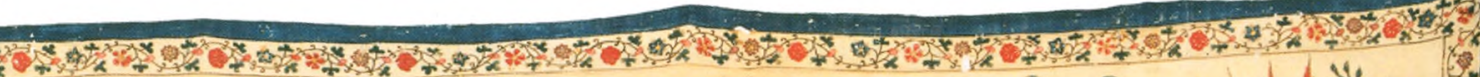
Q12 * 20 a र́C * T.

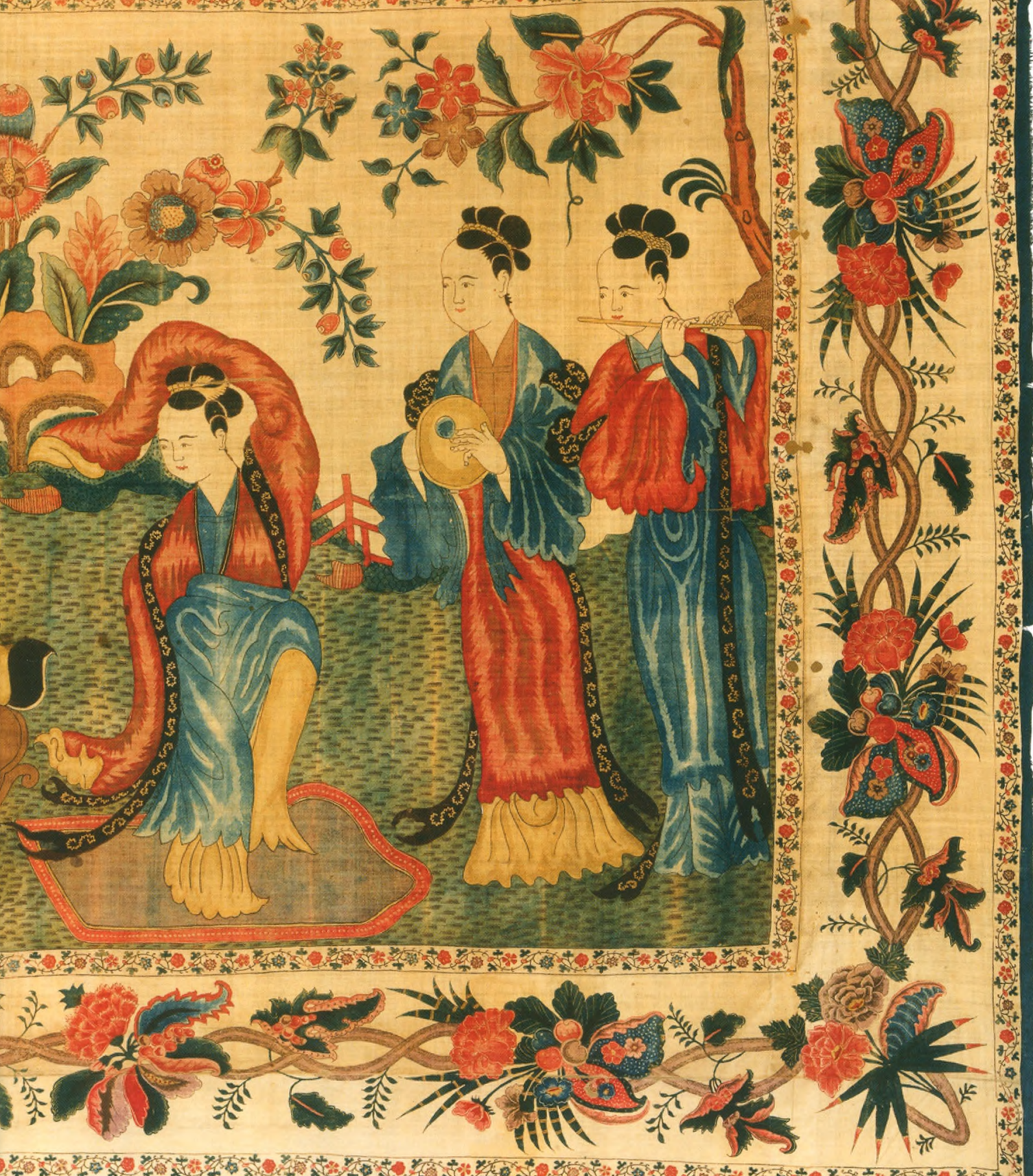




\section{$\ll$ Figure 12}

Chintz, decorated with a chinoiserie showing Chinese musicians, $247 \times 175 \mathrm{~cm}$, India, Coromandel Coast, ca. 1750, Croninger Museum, inv. no. 19890328.

\section{Chintz}

Another way to extract information from an object is to study it as an autonomous piece and use the results for wider vistas. Take, for example, the monumental Indian chintz in the Groningen Museum. It is a rectangular piece of cotton, measuring $247 \times 175$ centimetres, woven in India in an unknown workshop on the Coromandel Coast. The stain-dyed decoration in different colours shows a scene of Chinese figures in a landscape with flowering plants. Of the five women, three are playing music, one is dancing and the fifth holds a lantern. They are situated before a seated Chinese man, a servant with a parasol behind him. The central scene is surrounded by a wide border with linked fantastic flowers, framed by small borders of flowerheads. The edge is accentuated by a thick blue-black line. Closer inspection reveals that the upper part - with much fresher colours - was once folded backwards, while there are small holes along all the edges. Apparently the cloth, with its unusual and painterly chinoiserie scene, was once nailed to a wall (fig. 12).

Comparable pieces could not be traced in the extensive literature on export chintzes for the Western market. It is well known that since the 1650 s textiles from India were an important commodity for all Western trade companies, including the VOC. The Dutch exchanged them for spices and other goods as part of their inter-Asian trade. Painted and printed chintzes also sold very well in the Netherlands where they were used for upholstery and interior fittings but above all for women's clothing, deeply influencing fashion styles. Competition was based on design and was influenced by rapidly changing demands and vogues. Usually the decorations show flowers, plants, animals and landscapes, rarely Western scenes or people. A typical Western chinoiserie, as on this chintz, is extremely rare. Obviously it was ordered specially, most probably by a private customer. Given the general style it can be dated somewhere around the 1750 s.

The nail holes indicate its use as a wall cover, folded to make it fit into a slightly smaller frame. Strictly speaking this should be the end of our reflections, but as good scholars we could try to set our imaginations to work, based on the facts at our disposal. A theory is always welcome, as long as it is presented as a possibility and is open to rectification. In this case I would like to suggest that this chintz, depicting Asian people making music, was probably part of a set of four, symbolising the four continents Asia, Africa, America and Europe, with their inhabitants figuring as musicians. These four chintzes may have lined the walls in a music chamber, symbolising the universal appeal of music. This is but a theory, no more. I leave it to you, the next generation of art historians, to prove or discard it.

\section{Lacquer}

A third way, or method if you like, of approaching an object is by careful comparison. I illustrate this with two pieces of lacquer, one made in Japan, the other in the Netherlands. Both are rectangular cabinets on low feet and with two opening doors hinged on the sides. The inside is divided into compartments with deep drawers. The exuberantly worked hinges, lock and handles are prominently placed and have an incised decoration, Botb Bare $_{2}$ :56:14AM placed on later, European stands. 
The cabinet with drawers, or comptoir as it is named in 17th-century Dutch records, has a long typological history, harking back to 15th-century European wooden travel boxes. When the Portuguese came to trade in Japan in the 1540s, they introduced Western-style furniture, among them the travel box, which they had copied in Japanese lacquer. These Namban boxes were small, easily transportable and may have been used to store letters, precious objects, jewellery, etc. After the Dutch became seriously involved in the lacquer trade in the 1630s, they adopted the idea of the travel box, but ordered it as a large cabinet, a true piece of furniture. This was displayed prominently in colonial and domestic interiors, and served all kinds of purposes, from an archive to a cabinet of curiosities. Their decorations followed the demand of the Dutch customers, who did not like the heavy and relatively coarse pearlshell patterns that the Portuguese had introduced on export lacquer. They appreciated a more Japanese, painterly style that was initially confined within cartouches or panels, but they soon broke out of these boundaries and covered all the available surface. By the mid-17th century, this 'pictorial' style was firmly established and continued until the end of the 18th century as the main type of decoration on export lacquer.

The Japanese cabinet shows all the characteristics mentioned above.

The doors have a continuous, borderless decoration of a landscape with a river and a rocky shore, in gold lacquer on a black lacquered ground. On the left are small pavilions and a large pine tree amidst boulders. As is common in Japanese painting, the composition is asymmetrical without disturbing the

Figure 13a Lacquer cabinet or comptoir, height 78.5 cm, width $91.3 \mathrm{~cm}$, depth $50 \mathrm{~cm}$, Japan, 1660-1690, Groninger Museum, inv. no. 1991-

Figure 13b

The same cabinet with open doors. balance. Although they are gilded, the mounts heavily intrude on this golden landscape, but apparently this did not bother the buyer. Details are finely worked, parts are slightly raised and the entire scene gives the impression of a rich, exotic painting - which was just what the Dutch owner liked.

The fronts of the ten drawers inside the cabinet also have a high-quality decoration of mountainous landscapes with flying birds, trees and plants, in silver and gold lacquer. The backs of the doors are decorated with bamboo and a bird, while the sides and the back of the comptoir are plain black. This is a luxurious, expensive object and most years only the VOC could invest the sums required to buy this type of cabinet (figs. 13a and b).
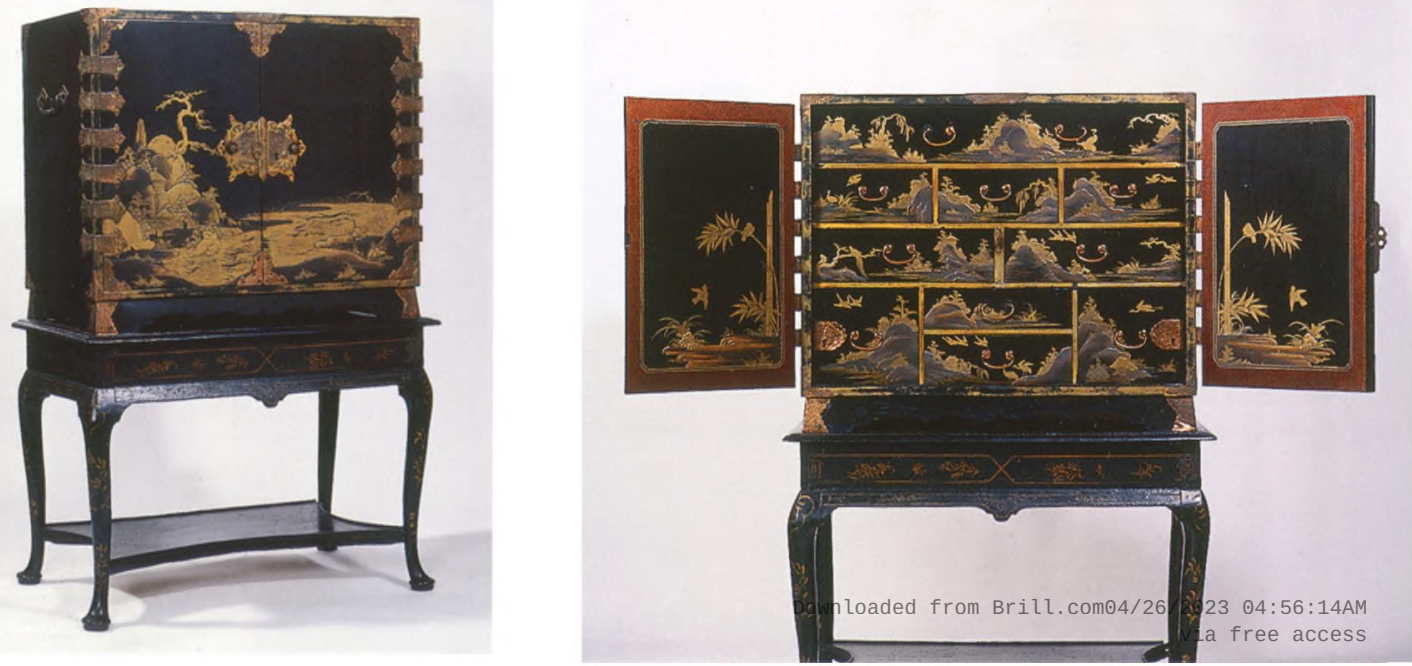
At the end of the 17th century, however, the Company had to economise on its lacquer orders, notwithstanding the profitable monopoly on the exports. The lacquer trade for the Netherlands dwindled and was given up altogether in the 1690s. As with porcelain in China and Japan, private individuals took over, but they rarely could afford large pieces of lacquer and reverted to small objects such as tea wares, dishes and plates, or small boxes.

Thus, the comptoir (and other Japanese lacquer) gradually became rare in the Netherlands and elsewhere in Europe. In order to fill the gaps in the markets, a European lacquer industry sprang up, trying to imitate the Japanese models. This proved to be an almost impossible task, because genuine lacquer is tapped from the lacquer tree (Rhus Vernificera), which does not grow in the West. Imports of this volatile raw material failed and European lacquer workers therefore experimented with all kinds of blackened varnishes, such as shellac. Decorations were done in 'gold' paint instead of gold lacquer. The differences are not always obvious because very good imitations were made, but in the case of this Dutch cabinet it is clear that it is not Japanese. The rectangular shape, the mounts, the interior drawers and the hinged doors follow the model, as does the continuation of the decoration in gold on a black ground across the two doors. However, the landscape has lost its Japanese qualities and is rendered as a chinoiserie. On the right in the foreground a group of Oriental people are gathered around a table, with perched birds to their left; on the far left is a rocky promontory with trees and

Figure 14a

Lacquered cabinet, imitating a Japanese comptoir, height $70 \mathrm{~cm}$, width $84 \mathrm{~cm}$, depth 44.5 cm, the Netherlands, ist half 18 th century, Groninger Museum, inv. no. 1990-0424.

Figure $14 b$

The same cabinet with open doors. flying or perched birds. The plain black space in between suggests a river. Although much effort was taken to paint the scene in gold in Japanese style, the composition is much more symmetrical and the natural autonomy of the Japanese landscape is lacking. The figures are clearly an Oriental fantasy, while the many birds were added to create an exotic effect. Similar figures and large birds in a landscape appear on the fronts of the interior drawers. In its own way this is a very well executed chinoiserie, cleverly using Oriental stylistic elements, but the European mind and conventions shine through everywhere. Nevertheless, this cabinet, most likely made in the Netherlands in the early 18th century, will have fulfilled its purpose as a good alternative to an unobtainable Japanese cabinet (figs. $14 a$ and $b$ ).
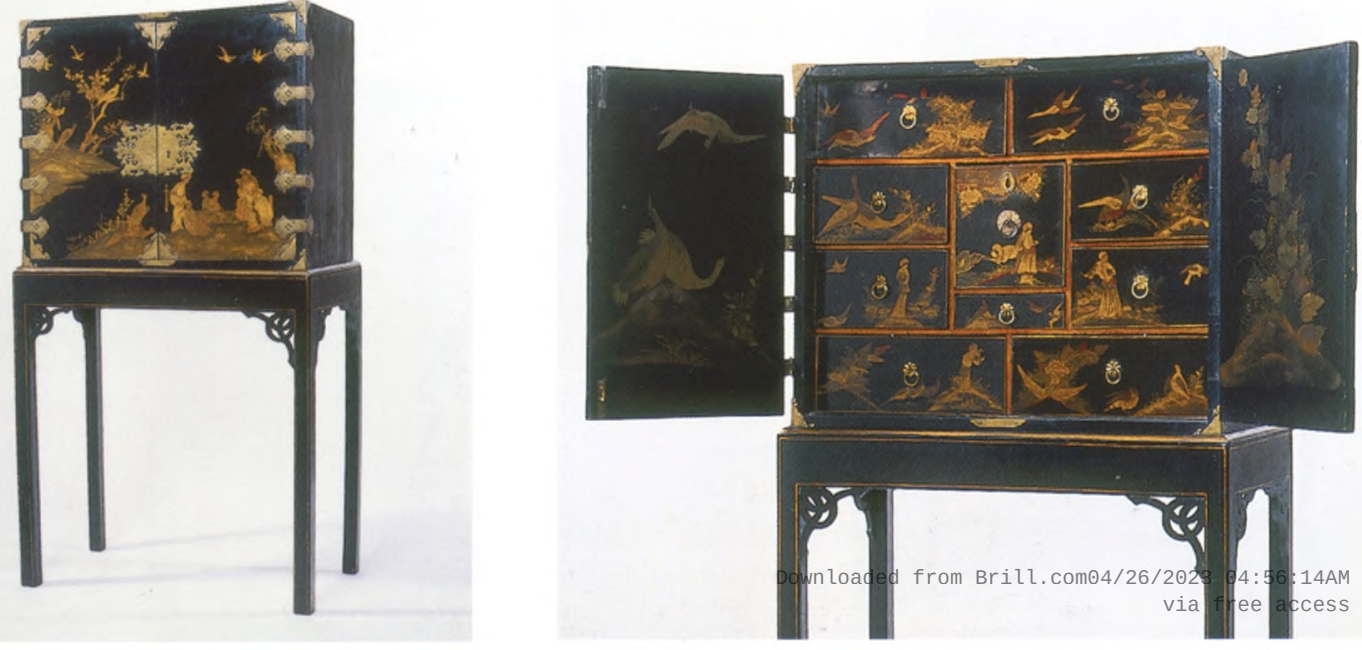
One of the puzzling aspects of Japanese export lacquer is the almost total absence of European designs. Apart from some rare 17th-century shields and dishes with family coats of arms, names or initials, no Japanese lacquer is known with Western landscapes, ships, figures or similar commande depictions that occur on Japanese export porcelain. It was only at the end of the 18th century that a fashion suddenly started for series of oval medallions decorated with portraits of famous European people, or rectangular plaques with city views and sea battles. These medallions and plaques were made of lacquered copper and the representations were copied from prints. In fact, one would have expected such decorations much earlier on cabinets, boxes, dishes, lacquered tea wares and other fashionable objects, especially when private orders took over in the late 17th century. Lacquer with Western shapes was ordered frequently, but not with Western decorations. One would think that if commande porcelain were ordered, commande lacquer would follow. Clearly, there was a market for exotic Japanese objects with Western designs, the contrast appealing to the buyer. I have no idea why this did not happen in lacquer and I very much hope that students of the next generation will be able to come up with an explanation (fig. 15).

\section{Silk}

China is the cradle of the world's silk production, and raw silk or manufactured silks - partly painted or embroidered - were shipped by the VOC to the Netherlands in huge quantities during the 18th century. Being a natural product, silk decays quickly, and of the thousands of bales of silk imported, only very few traces remain. In Dutch public collections only about five dozen examples of silk dresses, upholstery, religious vestments, wall hangings, curtains, bedspreads, etc., have been preserved, either complete or as fragments. The Groninger Museum has a vestment for the Catholic Cult, made in the second half of the 18th century from different types of Chinese silk. Part is ivory-white and has a woven pattern of flowering branches; other parts are hand-painted with flower sprays. The sections and the contours are accentuated with bands of gold-coloured woven silk (figs. 16a and b).

\section{Figure 15}

Lacquer medallion, depicting Childebert I, the Frankish King of Paris (r. 511-558), $12 \times$ $9.3 \mathrm{~cm}$, Japan, 1780-1800, Groninger Museum, inv. no. 1988 0308.

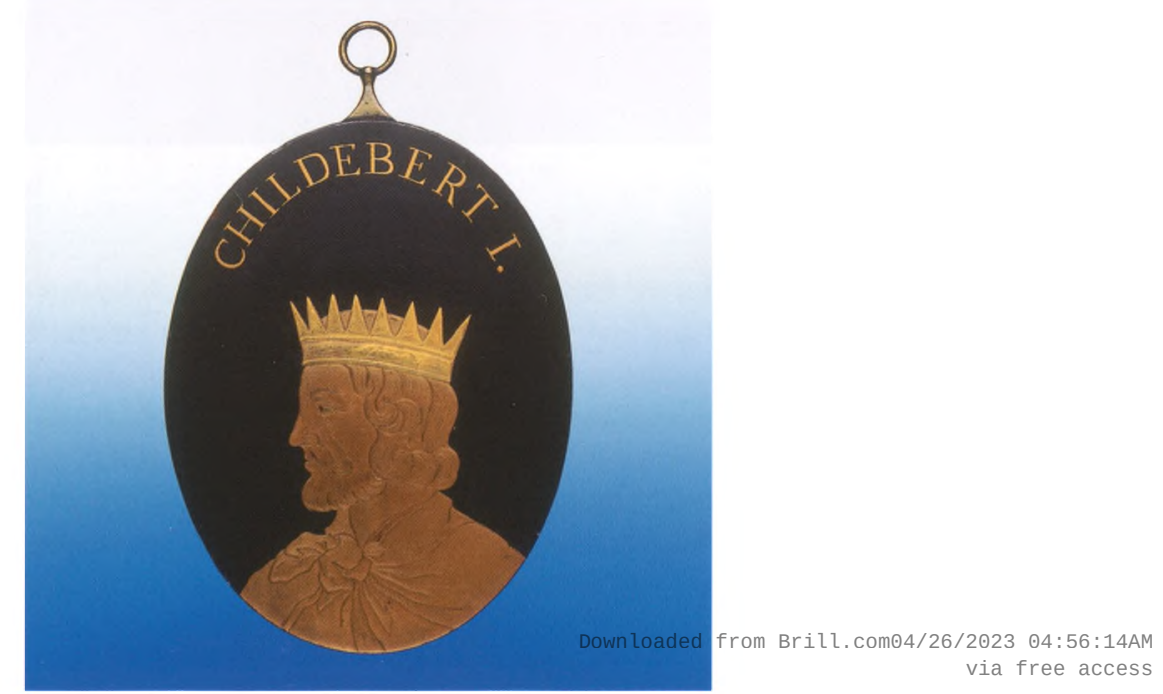




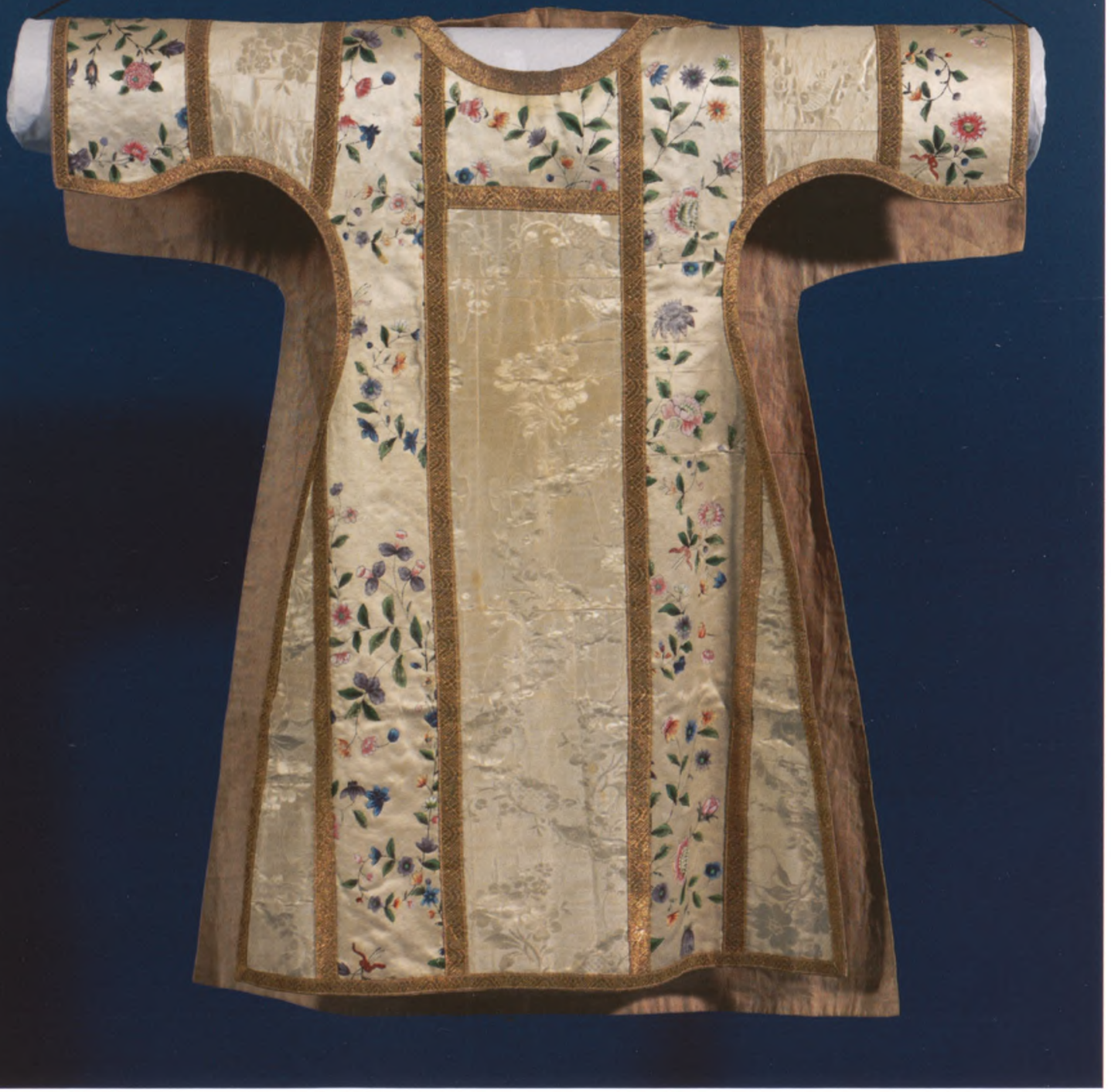

Figure $16 a$ and $b$ Vestment for use in the Catholic Church, Chinese silk and embroidery, length $110 \mathrm{~cm}$, width $100 \mathrm{~cm}$, mid-18th century, Groninger Museum, inv. no. 1984-0032.
It is obvious that the exotic Chinese silk was used to make this vestment more beautiful and impressive. As such, it fits into the general trend already noted that the exotic materials, shapes and decorations of the East were often used to add glamour and effect. However, this textile object also tells another, more recent story. I acquired it for the Museum at an auction in 1984. At that time, I had the ambition and support to build a collection of objects that would illustrate the theme of East-West interactions, based on the extensive holdings of export porcelain. Such a survey did not exist in this country, which I found strange given the important role the Dutch played $_{6}$ in $_{6}: 14 \mathrm{Am}$ 


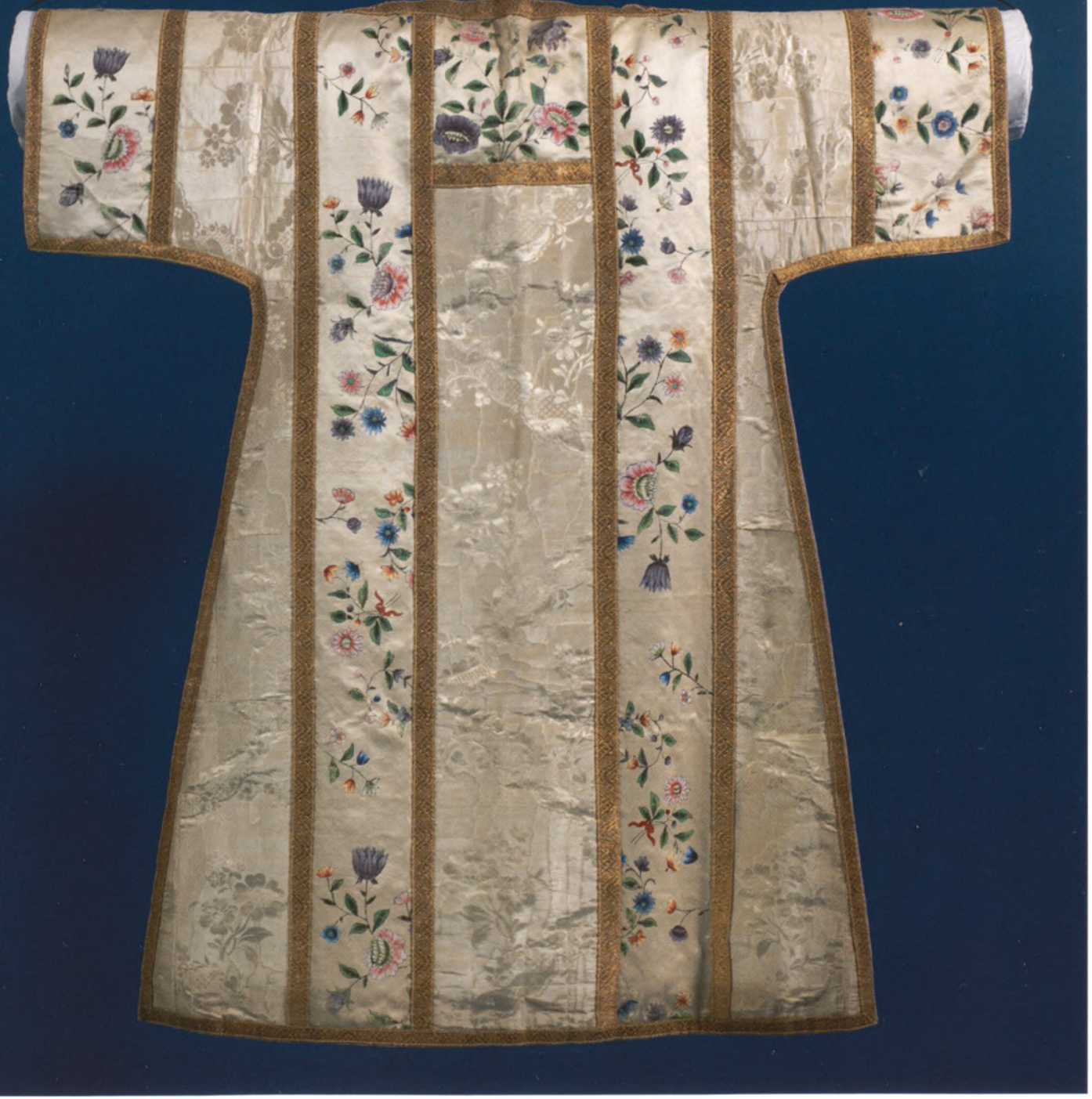

distributing Oriental objects in Europe and how these had influenced Western arts and crafts. My model was the Peabody-Essex Museum in Salem, Massachusetts, USA, with its amazing and extensive collection of export art, which so aptly illustrates exactly this field. I bought the vestment on an impulse, without knowing its provenance or if there was a relationship with Holland at all, in order to have a good example of the type. Alas, funding became scarce and shifting museum policies and priorities prevented the substantial expansion of the still embryonic collection. The vestment therefore is an isolated item now but nicely documents part of the history of ${ }_{6: 14 \mathrm{AM}}$ collecting by the Museum and the ideas of a curator. 


\section{Conclusion}

Over thirteen years, Leiden students have expressed a lively interest in the theme of East-West interactions, enjoying the global aspects of this study. My Asian students, too, have been among the forerunners of today's marked interest in the East for the history of mutual cultural relations and fashions. The interaction has also been strong in the personal field: students and I have learnt much from each other, enjoying our contacts.

In the end I am a storyteller and I think that has been my most important function as a teacher, a scholar and as an author. My former museum assistant John Leopold once told me: "The art object is just dead material, it is mute. It is our challenge as art historians to call it to life, to tell its story and give it a context." If I have done that and have generated enthusiasm in my audience for this challenge, I am a happy man. 